\author{
Professor Tudorel ANDREI, PhD (Corresponding author) \\ E-mail: andrei.tudorel@ csie.ase.ro \\ The Bucharest University of Economic Studies \\ Professor Régis BOURBONNAIS, PhD \\ E-mail: regis.bourbonnais@ dauphine.psl.eu \\ Laboratoire Economie Dauphine \\ Université Paris-Dauphine, Paris, France \\ Professor Bogdan OANCEA, PhD \\ University of Bucharest \\ E-mail: bogdan.oancea@faa.unibuc.ro \\ Andreea MIRICA, PhD \\ The Bucharest University of Economic Studies \\ E-mail: andreea.mirica@csie.ase.ro
}

\title{
MIXED MARRIAGES IN ROMANIA - THE CASE OF THE HUNGARIAN MINORITY
}

\begin{abstract}
Ethnically mixed marriages represent a crucial element for ensuring cohesion within communities characterised by a high diversity. This paper aims to point out the main factors that influence the likelihood of mixed marriages in areas from Romania where Romanians and Hungarians cohabitate. In this respect, anonymised census microdata are used. The study reveals that educational attainment, age difference between spouses and the number of Hungarians within the locality/village or municipality might have a significant effect on the likelihood of a person to engage in an ethnically mixed marriage. The effects are slightly different for men and women. marriage.

Keywords: logit model, ethnically mixed marriages, Hungarians, diversity,
\end{abstract}

JEL Classification: J12, J11

\section{A. Introduction}

Marriage, especially ethnically mixed marriage, is one of the most intensively researched fields in the social sciences (Dumănescu et al, 2014, Maarten van Ham and Tammaru, 2011). Moreover, the share of these marriages in the total number of marriages represents a cohesion indicator in a society (Monden and Smits, 2005). This subject is extremely important as information on mixed marriages can be included, ,into models of ethnological monitoring and early 
Tudorel Andrei, Régis Bourbonnais, Bogdan Oancea, Andreea Mirica

warning systems for ethnic conflicts (Smits, 2010, p.417), a necessity in a world where people of different race, religion and ethnicity coexist in a small areas (Blau and Schwartz, 1984).

The logit model is used in various studies, in economics, social, medicine etc., to identify the influence of some factors in modifying a variable. Next, we present some examples: the logit model is used to evaluate characteristics of the labour market [Andrei and Bourbonnais, 2017]; applying logit in health domain [Jones, 2007], education [Bailey, 2017], agriculture research [Adeogun, 2008] etc.

The probability for Hungarians, separate for male and female, to have a marriage with a partner who has other nationality is estimated using characteristics of person and their area of residence within the framework of a logit model:

$$
p_{i}=\frac{\exp \left(a_{0}+\sum_{j=1}^{12} a_{j} x_{j}\right)}{1+\exp \left(a_{0}+\sum_{j=1}^{12} a_{j} x_{j}\right)}
$$

where $x_{j}, j=1, \ldots, 12$ are the variables which assume that have an effect on mixed marriages.

The relation [1] can be written:

$$
\ln \frac{p_{i}}{1-p_{i}}=a_{0}+\sum_{j=1}^{12} a_{j} x_{j}
$$

Hungarians represent $6.5 \%$ of the permanent resident population registered at the 2011 Population and Housing Census in Romania, concentrated mostly in Transylvania, making studies with regard to mixed marriage, crucial. Such studies have focused on the historical perspective (for example, Horvath, 2014). The present study contributes to the literature because it uses an econometric approach using microdata from the Population and Housing Census, permitting and analysis by various variables on this phenomenon: sex, educational level of spouses and type of locality/village or municipality with regard to the number of Hungarians and age difference of the spouses. Sex was considered a relevant variable because literature showed that when forming a mixed marriage, men and women often have different behaviour within the partnership like for example, men being more likely to adopt the nationality of their spouse (Neyrand and M'Sili, 1998). Age difference between spouses was incorporated into the analysis because it may represent a crucial factor for the success of a mixed marriage (Schmitt, 1969). With regard to educational attainment, scientific literature pointed out that it may explain the willingness of both men and women to engage in a mixed marriage (Okun, 2004). Difference in educational level between partners within a marriage may be an indicator or whether the society is traditional or egalitarian, more specifically, if the woman has the highest educational attainment, the more likely the society may be egalitarian (Kalmijn,2013). Locality/villages and municipalities were grouped 
Mixed Marriages in Romania - The Case of the Hungarian Minority

according to the number of permanent resident Hungarians and included within the analysis because one of the main factors affecting the decision to marry is residential proximity of possible mates (Kulu and Hannemann, 2019).

\section{B. Data and methodology}

In order to perform the study, anonymised microdata for individuals and aggregated data at component localities and villages and municipalities level from the 2011 Population and Housing Census in Romania were used. Individual data include age, educational level and area of residency (urban or rural). Data at component localities and villages and municipalities level were computed based on individual data on usual residency and ethnicity, resulting in three indicators the share of Romanians, Hungarians and other ethnic groups, respectively. Moreover, three types of villages (with less than 50 Hungarians, between 50 and 100 and between 100 and 500) and three types of municipalities (with less than 1000 Hungarians, between 1000 and 5000 and over 5000) were defined based of the same data. The thresholds for this grouping were determined by analysing the distribution of the cities, villages and municipalities by size and choosing the corresponding quantiles.

In order to reveal as many aspects of mixed marriages as these microdata permit, logit models for men and women, respectively were used. Table 1 presents the variables used in these models.

Table 1.Variable used in the logit models for men and women

\begin{tabular}{|c|l|l|}
\hline Symbol & Name & Description \\
\hline$x_{1}$ & $\begin{array}{l}\text { The share of Romanians within } \\
\text { the village }\end{array}$ & $\begin{array}{l}\text { The number of Romanians divided } \\
\text { by the total number of permanent } \\
\text { residents within the village }\end{array}$ \\
\hline$x_{2}$ & $\begin{array}{l}\text { The share of persons other than } \\
\text { Romanians and Hungarians } \\
\text { within the village }\end{array}$ & $\begin{array}{l}\text { The number of persons that are } \\
\text { neither Romanians, nor Hungarians } \\
\text { divided by the total number of } \\
\text { permanent residents within the } \\
\text { village }\end{array}$ \\
\hline$x_{3}$ & $\begin{array}{l}\text { The share of Romanians within } \\
\text { the municipality }\end{array}$ & $\begin{array}{l}\text { The number of Romanians divided } \\
\text { by the total number of permanent } \\
\text { residents within the municipality }\end{array}$ \\
\hline$x_{4}$ & $\begin{array}{l}\text { The share of persons other than } \\
\text { Romanians and Hungarians } \\
\text { within the municipality }\end{array}$ & $\begin{array}{l}\text { The number of persons that are } \\
\text { neither Romanians, nor Hungarians } \\
\text { divided by the total number of } \\
\text { permanent residents within the } \\
\text { municipality }\end{array}$ \\
\hline
\end{tabular}


Tudorel Andrei, Régis Bourbonnais, Bogdan Oancea, Andreea Mirica

\begin{tabular}{|c|c|c|}
\hline$x_{51}$ & Age of male partner & $\begin{array}{l}\text { Computed based on the birth year } \\
\text { declared at the census }\end{array}$ \\
\hline$x_{52}$ & Age of female partner & $\begin{array}{l}\text { Computed based on the birth year } \\
\text { declared at the census }\end{array}$ \\
\hline$x_{5}$ & Age difference between spouses & $\begin{array}{l}\text { Absolute value of the difference } \\
\text { between the ages of the spouses }\end{array}$ \\
\hline$x_{6}$ & Area of residency & $\begin{array}{l}\text { Equals } 1 \text { if the couple lives within } \\
\text { the urban area and } 0 \text { if the couple } \\
\text { lives within the rural area. }\end{array}$ \\
\hline$x_{7}$ & $\begin{array}{l}\text { Difference in educational level } \\
\text { between the spouses }\end{array}$ & $\begin{array}{l}\text { The educational level of the } \\
\text { spouses in a categorical variable } \\
\text { taking the following values: } 1 \text { for } \\
\text { primary level, } 2 \text { for lower } \\
\text { secondary level, } 3 \text { for professional } \\
\text { level, } 4 \text { for upper secondary and } \\
\text { post-secondary level and } 5 \text { for } \\
\text { higher education. The difference } \\
\text { should be understood as difference } \\
\text { as difference in these levels }\end{array}$ \\
\hline$x_{8}$ & Village_under_50 & $\begin{array}{l}\text { Equals } 1 \text { if the number of } \\
\text { Hungarians within the village is } \\
\text { less than } 50 \text { in and } 0 \text { otherwise }\end{array}$ \\
\hline$x_{9}$ & Village_between_50_and_100 & $\begin{array}{l}\text { Equals } 1 \text { if the number of } \\
\text { Hungarians within the village is } \\
\text { between } 50 \text { and } 100 \text { and } 0 \\
\text { otherwise }\end{array}$ \\
\hline$x_{10}$ & Village_between_100_and_500 & $\begin{array}{l}\text { Equals } 1 \text { if the number of } \\
\text { Hungarians within the village is } \\
\text { between } 100 \text { and } 500 \text { and } 0 \\
\text { otherwise }\end{array}$ \\
\hline$x_{11}$ & municipality_under_1000 & $\begin{array}{l}\text { Equals } 1 \text { if the number of } \\
\text { Hungarians within the municipality } \\
\text { is under } 1000 \text { and } 0 \text { otherwise }\end{array}$ \\
\hline$x_{12}$ & $\begin{array}{l}\text { municipality } \\
\text { _between_1000_and_5000 }\end{array}$ & $\begin{array}{l}\text { Equals } 1 \text { if the number of } \\
\text { Hungarians within the municipality } \\
\text { is between } 1000 \text { and } 5000 \text { and } 0 \\
\text { otherwise }\end{array}$ \\
\hline
\end{tabular}


Mixed Marriages in Romania - The Case of the Hungarian Minority

\section{Results}

The initial set of models estimates the likelihood of a mixed marriage where one of the spouses is Hungarian, given the ethnic structure of the village or census area respectively. Thus the dependent variable is the number of mixed marriages with a Hungarian male partner and the number of mixed marriages with a Hungarian female partner respectively in the total number of marriages within the locality/village or municipality. The next set of models improves the initial model by introducing some characteristics of the spouses.

Table 2 presents the results of the first set of models, for men and women respectively.

Next, the LR test is used in order to assess whether or not important variables in assessing the likelihood of mixed marriages of Hungarians are excluded: firstly, the age difference between spouses, then the area of residency and finally the difference in educational level between the spouses are verified one at a time starting to the initial model. The results of the LR test (see table 3) show us that the three characteristics are relevant for the formation of a mixed marriage in the case of Hungarians both males as well as for females. The results reveal that the area of residency has a weak influence on the likelihood of a mixed marriage where the wife is a Hungarian. In this case, the probability of a type one error is $23 \%$ (table 4).

Next, considering the results of the LR test, model parameters are estimated for three more model sets, introducing an additional variable. The first one introduces the age difference between $\operatorname{spouses}\left(x_{5}\right)$, the second one, the area of residency $\left(x_{6}\right)$ and the third one the difference in educational level between the spouses $\left(x_{7}\right)$.

Additionally, the study analysis whether or not the number of Hungarians within a village or census area influences the likelihood of mixed marriages. Therefore, LR test is performed on the four model sets to assess whether or not variables $x_{8}, x_{9}, x_{10}, x_{11}, x_{12}$ should be also includen in the models. The results (see table 3) show that the type of village or census area defined by the number of Hungarians is an important variable that influences the share of mixed marriages where a partner is Hungarian in the total number of marriages at component locality/village or municipality.

Table 2. Model parameters estimates

\begin{tabular}{|l|l|l|l|l|}
\hline & Model 1 & Model 2 & Model 3 & Model 4 \\
\hline & \multicolumn{3}{|l|}{ The share of mixed marriages where the male partner is } \\
& $\begin{array}{l}\text { Hungarian in the total number of marriages at component } \\
\text { locality/village or municipality level }\end{array}$ \\
\hline $\mathrm{c}$ & -4.833 & -4.768 & -4.856 & -4.859 \\
& $(0.025)$ & $(0.026)$ & $(0.027)$ & $(0.027)$ \\
\hline
\end{tabular}


Tudorel Andrei, Régis Bourbonnais, Bogdan Oancea, Andreea Mirica

\begin{tabular}{|c|c|c|c|c|}
\hline$x_{1}$ & $\begin{array}{c}3.149 \\
(0.071)\end{array}$ & $\begin{array}{c}3.119 \\
(0.071)\end{array}$ & $\begin{array}{c}3.316 \\
(0.072)\end{array}$ & $\begin{array}{c}3.315 \\
(0.072)\end{array}$ \\
\hline$x_{2}$ & $\begin{array}{c}2.463 \\
(0.126)\end{array}$ & $\begin{array}{c}2.457 \\
(0.126)\end{array}$ & $\begin{array}{c}2.482 \\
(0.126)\end{array}$ & $\begin{array}{c}2.481 \\
(0.126)\end{array}$ \\
\hline$x_{3}$ & $\begin{array}{c}1.399 \\
(0.077)\end{array}$ & $\begin{array}{c}1.422 \\
(0.077)\end{array}$ & $\begin{array}{c}1.336 \\
(0.077)\end{array}$ & $\begin{array}{c}1.353 \\
(0.077)\end{array}$ \\
\hline$x_{4}$ & $\begin{array}{c}2.397 \\
(0.147)\end{array}$ & $\begin{array}{c}2.432 \\
(0.147)\end{array}$ & $\begin{array}{c}2.202 \\
(0.148)\end{array}$ & $\begin{array}{c}2.237 \\
(0.148)\end{array}$ \\
\hline$x_{5}$ & & $\begin{array}{c}0.019 \\
(0.002)\end{array}$ & $\begin{array}{c}0.020 \\
(0.002)\end{array}$ & $\begin{array}{c}0.020 \\
(0.016)\end{array}$ \\
\hline$x_{6}$ & & & $\begin{array}{c}0.167 \\
(0.016)\end{array}$ & $\begin{array}{c}0.173 \\
(0.016)\end{array}$ \\
\hline$x_{7}$ & & & & $\begin{array}{l}-0.195 \\
(0.010)\end{array}$ \\
\hline $\begin{array}{l}\text { McFadden } \\
\text { R-squared }\end{array}$ & 0.213 & 0.214 & 0.214 & 0.216 \\
\hline & \multicolumn{4}{|c|}{$\begin{array}{l}\text { The share of mixed marriages where the female partner is } \\
\text { Hungarian in the total number of marriages at component } \\
\text { locality/village or municipality level }\end{array}$} \\
\hline $\mathrm{c}$ & $\begin{array}{l}-4.321 \\
(0.022)\end{array}$ & $\begin{array}{l}-4.233 \\
(0.022)\end{array}$ & $\begin{array}{l}-4.252 \\
(0.024)\end{array}$ & $\begin{array}{l}-4.253 \\
(0.024)\end{array}$ \\
\hline$x_{1}$ & $\begin{array}{c}3.678 \\
(0.073)\end{array}$ & $\begin{array}{c}3.645 \\
(0.073)\end{array}$ & $\begin{array}{c}3.682 \\
(0.075)\end{array}$ & $\begin{array}{c}3.682 \\
(0.075)\end{array}$ \\
\hline$x_{2}$ & $\begin{array}{c}2.693 \\
(0.126)\end{array}$ & $\begin{array}{c}2.689 \\
(0.126)\end{array}$ & $\begin{array}{c}2.693 \\
(0.126)\end{array}$ & $\begin{array}{c}2.694 \\
(0.126)\end{array}$ \\
\hline$x_{3}$ & $\begin{array}{c}0.220 \\
(0.077)\end{array}$ & $\begin{array}{c}0.240 \\
(0.077)\end{array}$ & $\begin{array}{c}0.227 \\
(0.077)\end{array}$ & $\begin{array}{c}0.226 \\
(0.077)\end{array}$ \\
\hline$x_{4}$ & $\begin{array}{c}1.498 \\
(0.146)\end{array}$ & $\begin{array}{c}1.541 \\
(0.146)\end{array}$ & $\begin{array}{c}1.492 \\
(0.147)\end{array}$ & $\begin{array}{c}1.488 \\
(0.147)\end{array}$ \\
\hline$x_{5}$ & & $\begin{array}{c}0.026 \\
(0.002)\end{array}$ & $\begin{array}{c}0.026 \\
(0.002)\end{array}$ & $\begin{array}{c}0.026 \\
(0.002)\end{array}$ \\
\hline$x_{6}$ & & & $\begin{array}{c}0.036 \\
(0.016)\end{array}$ & $\begin{array}{c}0.035 \\
(0.016)\end{array}$ \\
\hline$x_{7}$ & & & & $\begin{array}{c}0.023 \\
(0.010)\end{array}$ \\
\hline $\begin{array}{l}\text { McFadden } \\
\text { R-squared }\end{array}$ & 0.181 & 0.182 & 0.182 & 0.183 \\
\hline
\end{tabular}


Mixed Marriages in Romania - The Case of the Hungarian Minority

Table 3. The LR test of omitting variables from Model 1

\begin{tabular}{|l|c|}
\hline & Female partner \\
\hline LR1 $\left(x_{5}\right)$ & $241.29(0.00)$ \\
\hline LR1 $\left(x_{6}\right)$ & $1.42(0.23)$ \\
\hline LR1 $\left(x_{7}\right)$ & $4.43(0.04)$ \\
\hline & Male partner \\
\hline LR1 $\left(x_{5}\right)$ & $134.62(0.00)$ \\
\hline LR1 $\left(x_{6}\right)$ & $90.84(0.00)$ \\
\hline LR1 $\left(x_{7}\right)$ & $379.28(0.04)$ \\
\hline
\end{tabular}

Table 4. The LR test of omitting variables from Model 4

\begin{tabular}{|l|r|}
\hline & \multicolumn{1}{|c|}{ Female partner } \\
\hline LR1 $\left(x_{8}\right)$ & $715.07(0.00)$ \\
\hline LR1 $\left(x_{9}\right)$ & $23.31(0.00)$ \\
\hline LR1 $\left(x_{10}\right)$ & $14.75(0.00)$ \\
\hline LR2 $\left(x_{11}\right)$ & $439.24(0.00)$ \\
\hline LR2 $\left(x_{12}\right)$ & $35.91(0.00)$ \\
\hline & Male partner \\
\hline LR1 $\left(x_{8}\right)$ & $1022.59(0.00)$ \\
\hline LR1 $\left(x_{9}\right)$ & $5.31(0.00)$ \\
\hline LR1 $\left(x_{10}\right)$ & $17.10(0.00)$ \\
\hline LR2 $\left(x_{11}\right)$ & $473.04(0.00)$ \\
\hline LR2 $\left(x_{12}\right)$ & $6.27(0.00)$ \\
\hline
\end{tabular}

Considering the results obtained after applying the LR test for the variables regarding the type of village or census area, four new model sets are computed, introducing these five variables within the four models from table 2. The parameters estimates of these models are displayed in table 5.

The new results show that for the villages where the number of Hungarians is low, the likelihood of mixed marriages for males as well as for females increases. The results are similar for municipalities, yet, the influence is much lower. Considering the type of residency, the models reveal that mixed marriages are more likely to occur in urban and in rural areas. With regard to education, one can observe that it has a different influence on mixed marriages where the male partner is Hungarian compared to mixed marriages where the female partner is Hungarian. In the case, the educational level of the non-Hungarian partner is higher, while in the second case the educational level of the non-Hungarian partner is lower. 
Tudorel Andrei, Régis Bourbonnais, Bogdan Oancea, Andreea Mirica

Table 5. Model parameters estimates after introducing the type village and census area

\begin{tabular}{|c|c|c|c|c|}
\hline & Model 1 & Model 2 & Model 3 & Model 4 \\
\hline & \multicolumn{4}{|c|}{$\begin{array}{l}\text { The share of mixed marriages where the male partner is } \\
\text { Hungarian in the total number of marriages at village or census } \\
\text { area level }\end{array}$} \\
\hline $\mathrm{c}$ & $\begin{array}{l}-4.821 \\
(0.026)\end{array}$ & $\begin{array}{l}-4.743 \\
(0.026)\end{array}$ & $\begin{array}{l}-4.539 \\
(0.029)\end{array}$ & $\begin{array}{l}-4.540 \\
(0.029)\end{array}$ \\
\hline$x_{1}$ & $\begin{array}{c}3.221 \\
(0.072)\end{array}$ & $\begin{array}{c}3.199 \\
(0.072)\end{array}$ & $\begin{array}{c}2.961 \\
(0.074)\end{array}$ & $\begin{array}{c}2.956 \\
(0.075)\end{array}$ \\
\hline$x_{2}$ & $\begin{array}{c}2.363 \\
(0.125)\end{array}$ & $\begin{array}{c}2.358 \\
(0.126)\end{array}$ & $\begin{array}{c}2.320 \\
(0.127)\end{array}$ & $\begin{array}{c}2.317 \\
(0.127)\end{array}$ \\
\hline$x_{3}$ & $\begin{array}{c}1.169 \\
(0.079)\end{array}$ & $\begin{array}{c}1.177 \\
(0.079)\end{array}$ & $\begin{array}{c}1.104 \\
(0.079)\end{array}$ & $\begin{array}{c}1.120 \\
(0.079)\end{array}$ \\
\hline$x_{4}$ & $\begin{array}{c}1.737 \\
(0.150)\end{array}$ & $\begin{array}{c}1.745 \\
(0.150)\end{array}$ & $\begin{array}{c}1.780 \\
(0.151)\end{array}$ & $\begin{array}{c}1.808 \\
(0.151)\end{array}$ \\
\hline$x_{5}$ & - & $\begin{array}{c}0.023 \\
(0.002) \\
\end{array}$ & $\begin{array}{c}0.023 \\
(0.002)\end{array}$ & $\begin{array}{c}0.022 \\
(0.002) \\
\end{array}$ \\
\hline$x_{6}$ & - & - & $\begin{array}{l}-0.357 \\
(0.022)\end{array}$ & $\begin{array}{l}-0.358 \\
(0.022) \\
\end{array}$ \\
\hline$x_{7}$ & - & - & - & $\begin{array}{l}-0.206 \\
(0.010)\end{array}$ \\
\hline$x_{8}$ & $\begin{array}{c}0.765 \\
(0.038)\end{array}$ & $\begin{array}{c}0.769 \\
(0.038)\end{array}$ & $\begin{array}{c}0.887 \\
(0.038)\end{array}$ & $\begin{array}{c}0900 \\
(0.039)\end{array}$ \\
\hline$x_{9}$ & $\begin{array}{c}0.189 \\
(0.048)\end{array}$ & $\begin{array}{c}0.200 \\
(0.048)\end{array}$ & $\begin{array}{c}0.291 \\
(0.049)\end{array}$ & $\begin{array}{c}0.301 \\
(0.049)\end{array}$ \\
\hline$x_{10}$ & $\begin{array}{c}0.083 \\
(0.036)\end{array}$ & $\begin{array}{c}0.091 \\
(0.036)\end{array}$ & $\begin{array}{c}0.154 \\
(0.037)\end{array}$ & $\begin{array}{c}0.161 \\
(0.037)\end{array}$ \\
\hline$x_{11}$ & $\begin{array}{c}0.324 \\
(0.023)\end{array}$ & $\begin{array}{c}0.341 \\
(0.023)\end{array}$ & $\begin{array}{c}0.577 \\
(0.027)\end{array}$ & $\begin{array}{c}0.584 \\
(0.027)\end{array}$ \\
\hline$x_{12}$ & $\begin{array}{c}0.223 \\
(0.015)\end{array}$ & $\begin{array}{c}0.232 \\
(0.015)\end{array}$ & $\begin{array}{c}0.343 \\
(0.017)\end{array}$ & $\begin{array}{c}0.349 \\
(0.017)\end{array}$ \\
\hline \multirow[t]{2}{*}{$\begin{array}{l}\text { McFadden } \\
\text { R-squared }\end{array}$} & 0.219 & 0.220 & 0.221 & 0.223 \\
\hline & \multicolumn{4}{|c|}{$\begin{array}{l}\text { The share of mixed marriages where the female partner is } \\
\text { Hungarian in the total number of marriages at componen } \\
\text { locality/village or municipality level }\end{array}$} \\
\hline c & $\begin{array}{l}-4.296 \\
(0.023)\end{array}$ & $\begin{array}{l}-4.199 \\
(0.023)\end{array}$ & $\begin{array}{l}-3.959 \\
(0.025)\end{array}$ & $\begin{array}{l}-3.960 \\
(0.025)\end{array}$ \\
\hline$x_{1}$ & $\begin{array}{c}3.502 \\
(0.075)\end{array}$ & $\begin{array}{c}3.479 \\
(0.075)\end{array}$ & $\begin{array}{c}3.187 \\
(0.077)\end{array}$ & $\begin{array}{c}3.187 \\
(0.077)\end{array}$ \\
\hline
\end{tabular}


Mixed Marriages in Romania - The Case of the Hungarian Minority

\begin{tabular}{|c|c|c|c|c|}
\hline$x_{2}$ & $\begin{array}{c}2.505 \\
(0.124)\end{array}$ & $\begin{array}{c}2.500 \\
(0.125)\end{array}$ & $\begin{array}{c}2.460 \\
(0.126)\end{array}$ & $\begin{array}{c}2.460 \\
(0.126)\end{array}$ \\
\hline$x_{3}$ & 0.261 & 1.265 & 0.170 & 0.169 \\
& $(0.079)$ & $(0.079)$ & $(0.080)$ & $(0.080)$ \\
\hline$x_{4}$ & 1.174 & 1.186 & 1.252 & 1.248 \\
& $(0.149)$ & $(0.149)$ & $(0.151)$ & $(0.151)$ \\
\hline$x_{5}$ & - & 0.029 & 0.028 & 0.028 \\
& & $(0.002)$ & $(0.002)$ & $(0.002)$ \\
\hline$x_{6}$ & - & - & -0.472 & -0.472 \\
& & & $(0.022)$ & $(0.022)$ \\
\hline$x_{7}$ & - & - & - & 0.018 \\
& & & & $(0.010)$ \\
\hline$x_{8}$ & 0.915 & 0.923 & 1.076 & 1.076 \\
& $(0.038)$ & $(0.038)$ & $(0.038)$ & $(0.039)$ \\
\hline$x_{9}$ & 0.095 & 0.103 & 0.221 & 0.221 \\
& $(0.051)$ & $(0.051)$ & $(0.052)$ & $(0.052)$ \\
\hline$x_{10}$ & 0.108 & 0.114 & 0.200 & 0.198 \\
& $(0.040)$ & $(0.037)$ & $(0.038)$ & $(0.038)$ \\
\hline$x_{11}$ & 0.180 & 0.200 & 0.515 & 0.515 \\
& $(0.023)$ & $(0.023)$ & $(0.028)$ & $(0.028)$ \\
\hline$x_{12}$ & 0.112 & 0.124 & 0.286 & 0.286 \\
& $(0.015)$ & $(0.015)$ & $(0.017)$ & $(0.017)$ \\
\hline McFadden & 0.187 & 0.188 & 0.190 & 0.191 \\
squared & & & & \\
\hline
\end{tabular}

D. Conclusions

The aim of this study was to analyse the factors that influence the likelihood of mixed marriages of Hungarians at the level of component localities/villages and municipalities areas. The study revealed that this likelihood increases if the number of Hungarians within the component locality/viillage or municipality is low and the family is settled in an urban area.

The study reveals that the educational level has a different influence on mixed marriages where a partner is a Hungarian male compared to a one where a partner is a Hungarian female. In a mixed marriage where the female belongs to the Hungarian ethnic group, she has the highest educational level within the couple. In a mixed marriage where the male belongs to the Hungarian ethnic group, he has the lowest educational level within the couple. The results are consistent with similar studies within the literature (see for example Qian, 1997).

\section{ACKNOWLEDGEMENTS}

Funding: This work was funded by a grant of the Romanian National Authority for Scientific Research and Innovation, CNDS-UEFISCDI, project number PNIII-P4-ID-PCCF-2016-0084.

Conflict of Interest: The authors declare that they have no conflict of interest. 
Tudorel Andrei, Régis Bourbonnais, Bogdan Oancea, Andreea Mirica

\section{REFERENCES}

[1]Adeogu, O.A, Ajana, A. M. (2008), Application of Logit Model in Adoption Decision: A Study of Hybrid Clarias in Lagos State, Nigeria. American-Eurasian Journal Agriculture and Environment Science, 4(4), 468-472;

[2]Andrei, T., Bourbonnais, R. (2017), Econometrie - teorie si aplicatii.

Economica Publishing, Bucharest;

[3]Bailey, M. (2017), Real Econometrics. Oxford University Press, New York;

[4]Blau, P.M., Schwartz, J.E. (1984), Crosscutting Social Circles. Academic

Press Orlando, FL;

[5]Dumanescu L., Marza D., Eppel M. (2014), Intermarriage throughout

History. Cambridge Scholar Publishing, Newcastle upon Tyne;

[6]Horváth I. (2014), Hungarians of Romania: Demographic Dynamics for the

Past one and a Half Century. Historia Actual Online 34,115-125;

[7]Jones, A. (2007), Applied Econometrics for Health Economists. Radcliffe

Publishing, Oxford;

[8]Kalmijn, M. (2013), The Educational Gradient in Marriage: A Comparison of 25 European Countries. Demography, 50(4), 1499-1520;

[9]Kulu, H. \& Hannemann, T. (2019), Mixed Marriage among Immigrants and their Descendants in the United Kingdom: Analysis of Longitudinal Data with Missing Information. Population Studies, 73(2), 179-196;

[10]Maarten van Ham and Tammaru, T. (2011), Ethnic Minority-Majority

Unions in Estonia Unions; European Journal of Population, (27): 313 - 335;

[11]Monden, C., Smits, J. (2005), Ethnic Intermarriage in Times of Social

Change: The Case of Latvia. Demography, 42 (2), 323-345;

[12]Neyrand, G. \& M'Sili, M. (1998), Mixed Couples in Contemporary France.

Marriage, Acquisition of French Nationality and Divorce. Population: An

English Selection, 385-416;

[13]Okun, B. S. (2004), Insight into Ethnic Flux: Marriage Patterns among Jews of Mixed Ancestry in Israel. Demography, 41(1), 173-187;

[14]Qian, Z. (1997), Breaking the Racial Barriers: Variations in Interracial Marriage between 1980 and 1990. Demography, 34(2), 263-276;

[15]Schmitt, R. C. (1969), Age and Race Differences in Divorce in Hawaii.

Journal of Marriage and the Family, 48-50;

[16]Smits, J. (2010), Ethnic Intermarriage and Social Cohesion. What Can We

Learn from Yugoslavia?. Social Indicators Research, 96(3),417-432. 